\title{
Smart Technology Integration in the System of Bachelors' Language Training
}

\author{
https://doi.org/10.3991/ijet.v14i15.10565 \\ Renata Elsakova $\left.{ }^{(}\right)$, Nadezhda Kuzmina, Daria Kochkina \\ "South Ural State University (National Research University)", Chelyabinsk, Russian Federation \\ sultanbekovarz@susu.ru
}

\begin{abstract}
This paper considers the problem of smart technology integration into the system of bachelors' language training at higher school environment. The use of smart technology in education helps to enrich traditional teaching methods and bring positive learning outcome. However, the application of smart technologies is connected with challenges both educators and students can face. The aim of the article is to consider and assess the use of smart technologies implemented into a foreign language teaching process. For that purpose, we applied such methods as a needs analysis (among lecturers of English from South Ural State University), a questionnaire and an interview (among three groups of students from similar bachelor's program). The findings show that the majority of those surveyed do understand the importance of smart technology for professional education, but they are not familiar with the types of smart technologies and how to use them. Based on the results of this analysis, the authors applied smart technologies in the process of English teaching, such as different language learning platforms (Edmodo, TEDed), social networks (VKontakte, Facebook), and a new online language development course, "English for General Purposes" which was implemented through the Moodle (the university corporate learning management system). The analyzed results and the drawn conclusions indicate that the integration of smart technologies allows to boost foreign language skills and encourage motivation.
\end{abstract}

Keywords - Smart education, smart university, smart technology integration, language training, learning management system (LMS), social networks, language learning platforms

\section{Introduction}

The entry of the humankind into the digital era and the fourth industrial revolution have inevitably led to fundamental changes in all spheres of social, cultural and economic life, such as the advent of a "smart" society, the creation of "smart" enterprises, the introduction of the concept of Industrial Internet and the Internet of things.

Transformations caused by the influence of Industry 4.0 have led to the replacement of "classical" education with smart education, traditional training - with smart training, traditional universities - with smart universities. 
To survive in the realities of a network society and increase competitiveness, leading Russian universities are restructuring their growth strategies in response to the challenges of the fourth industrial revolution. In 2013 the state program was launched to support leading Russian universities (Project 5-100). South Ural State University, being one of 21 participants of this project, determines its main goal as the transformation into a SMART university and prioritizes training of a new generation of leaders capable of facing global challenges of sustainable development and changing the world for the better.

Creating smart educational environment in the university supposes implementing the principles of flexibility in an interactive educational environment (digitalization of education), free access to the content around the world, personalization of teaching, project approach and creation of an integrative scientific and creative space.

In these circumstances, it is necessary to use smart technologies that allow different categories of learners to acquire necessary skills autonomously in an interactive form, exchange content, get feedback, and develop educational products. For this purpose, SUSU organizes its own production of modern teaching aids, develops modern forms of distance learning - e-learning and b-learning, as well as mass distance courses in the MOOC format.

Smart technologies include various digital platforms (Facebook, Edmodo, TED, Google docs), online communities (blogs, Twitter), mobile applications, digital tutorials and e-books, presentation tools, LMS (Moodle, Coursera, EdX), webinars and other digital media, the use of which is possible both from a desktop computer or laptop, and from smart devices (tablet, smartphone, smart TV). At the same time, the use of smart technologies does not deny the use of traditional means, forms and methods of teaching, but only offers alternative ways of obtaining and broadcasting educational information, new channels of interaction between educators and students. Proper application of smart technologies creates a smart learning environment that is selfdirected (S), motivating (M), adaptive (A), resource-enriched (R), technologyembedded (T) [1].

In the context of foreign language training at the university, the main reasons for incorporating smart technologies are connected with the need to enrich the learning process with authentic modern resources, encourage communication in real and online contexts, educate and communicate using English beyond the study-room, and develop the students' ability to learn a foreign language autonomously.

However, despite the undoubted advantages of using smart technologies in foreign language training at the university, not all participants of the educational process realize the importance and necessity of integrating this innovative tool into teaching and learning processes. The reasons can be very diverse: a negative attitude towards the digitalization of education, low level of computer literacy, the discrepancy between the selected technology and pedagogical goals and tasks, difficulties in solving users' problems, much time and effort to develop, implement and support courses.

The purpose of the research is to provide theoretical substantiation and assessment of the ways to integrate smart technologies into the system of bachelors' language training at higher school. To reach that complex aim it's essential, firstly, to gain an insight into bachelors' and educators' understanding of smart technologies for learn- 
ing a foreign language, secondly, to find out the reasons for incorporating this technology into the process of teaching and studying a foreign language and, thirdly, to examine benefits both for educators and learners from applying this technology in practice.

The subject matter of the study is the process of language training at the nonlinguistic higher school. The scope of the study is smart technology integration into bachelors' language training.

The purpose of the article is to highlight approaches which can show educators how to implement smart technologies in English teaching and reveal advantages and disadvantages while working with this or that instrument.

The investigation of the research problem is necessary to begin with giving theoretical background and literature review.

\section{$2 \quad$ Literature Review}

The question of smart technologies integration into the educational process is revealed by scientists primarily in the context of using computer-assisted technologies in teaching to different categories of learners: in elementary school [2], in secondary school [3], in the system of higher education [1]. At the same time, regardless of the level of education, more and more scientific publications describe the positive effect from the implemented e-learning tools: increasing students' involvement and motivation of [4], expanding the range of interaction patterns and increasing students' opportunities [5], enriching students' experience and applying knowledge in practical situations [6].

However, some researchers express concern about negative consequences of introducing smart technologies, as well as problems that accompany or result from such experiments. These shortcomings can be divided into two categories: technological and non-technological. Technological problems include the following: no access to smart-technologies at places with poor coverage of high-speed Internet [7], high cost of equipment / service and other financial issues [8]. Non-technological problems include the negative psychological effect [9], cheating during tests and distractions during class time, teachers' lack of technical and theoretical knowledge [10].

The efforts of scientists developing the issues of smart technologies integration are also aimed at finding and selecting effective smart tools suitable for the purposes of a particular discipline: for mathematics in secondary school [3], for teaching financial disciplines to students of higher educational institutions [11], in the system of teaching foreign languages [12] and others.

Since the subject matter of our study is the process of language training at the nonlinguistic higher school, we will consider in more detail the authors' interpretation of principles and approaches in terms of organizational aspects of teaching a foreign language in the university environment. Researchers working on the development of this subject area are aimed at studying such issues as: changing the teacher's role as a result of smart technologies implementation and increasing students' autonomy in learning a foreign language [13], didactic peculiarities of teaching a foreign language 
for academic and scientific purposes in smart-education [14], the use of smart technologies in the system of part-time education [15], the organization of students' selfguided work using smart technologies to study a foreign language for professional purposes [16]. With all the variety of available publications, studies concerning smart technology integration into the system of bachelors' language training are rather limited.

Before proceeding to the description of the research methodology and the introduction of smart tools incorporated into language teaching, it is necessary to clarify the key concept of the research which is "smart technology". There is no one generally accepted definition for this term. In Oxford Dictionary technology means "the application of scientific knowledge for practical purposes, especially in industry" (https://en.oxforddictionaries.com/definition/technology) and smart is explained as "(of device) of some independent action" (https://en.oxforddictionaries.com/ definition/smart).

Combining these two concepts O. Kalugina (2018) and N. Tarasevich (2018) define smart technologies as "technologies which have educational utility, programmed so as to be capable of independent actions giving students and teachers an access to the world outside a classroom" [12].

Following this definition, an important characteristic of smart technologies is providing continuous access to content from around the world. In other words, smart technology is the key to getting education outside the classroom in digital form.

Another important feature of smart technologies - interactivity - is emphasized in E. Zhdanov's definition (2015): "Smart technologies in education are technologies based on combining technical, pedagogical resources for teaching in an interactive educational environment with the help of specially developed content" [17]. The feature of interactivity manifests itself not only in the use of multimedia, but also in interaction with the surrounding environment, the ability to instantly respond and adapt to changing conditions. This shows the flexibility of smart technologies and the ability to adopt them to learners' individual needs which makes personalization of education real.

Having analyzed the above definitions, we define smart technologies as online technologies that allow both teachers and students to produce digital learning resources and use their own as well as authentic content from around the world to learn a foreign language in an interactive educational environment. Based on the results of theoretical analysis, we consider applying the following smart technologies in the process of English teaching: different language learning platforms (Edmodo, TEDed), social networks (VKontakte, Facebook), and a new online language development course, "English for General Purposes" which was specially designed and implemented through the Moodle.

\section{$3 \quad$ Methodology}

There were three different stages in our research and analysis; firstly a study of methodologies, secondly the findings from questionnaires distributed to bachelors and 
interviews with them, finally a needs analysis among educators-lecturers of English from South Ural State University, which focused on their experience in smart technologies.

The recipients were to indicate their institute or high school at the university, sex, and age and then to answer five questions in the questionnaire:

- What types of smart technologies for learning a foreign language do you know?

- What types of smart technologies do you use more often at the university?

- What is a smart technology used for?

- How often do you use smart technologies for learning a foreign language?

- Do you think that bachelors should learn basics of smart technologies not only in their native language but in English as well?

Bachelors were also interviewed. Educators (lecturers of English) from South Ural State University answered two questions in the interview:

- What types of smart technologies would you like to learn how to use in English?

- What challenges do you face in using smart technologies in English?

\subsection{Rationale of the questionnaire and the interview in the research}

The method of a questionnaire is popular for its anonymity, thus letting the participants feel free when answering the questions. The combination of closed and openended questions provides both information that can be easily converted into quantitative (e.g. count "yes" or "no") and qualitative (e.g. analysis of words used to express opinions) data.

There are also some disadvantages of questionnaires. First, they may not be informative in the analysis of emotions or feelings. Secondly, they lack details, because the space for writing answers is limited. Unlike questionnaires, interviews allow researchers to get more information about the subject matter; respondents' answers are more spontaneous and reflect their thinking process in speech.

In our questionnaire, we got data on how familiar bachelors are with different aspects of smart technologies in general. The interview highlighted bachelors' level of competence in using smart technologies in English.

\subsection{Participants}

The participants of the questionnaire were students from similar bachelor's program at South Ural State University (national research university), Chelyabinsk, Russia. The experiment was carried out in February 2018. Bachelors from the similar program were asked if they would participate in this study by completing the questionnaire and answering the questions of the interview.

Almost all students approached agreed to participate, and a total of 50 completed questionnaires were obtained and interviews taken. Although the questionnaire and the interview did not obtain responses from all the students in the university, some 
interesting pointers to their understanding of smart technologies in the language learning process have emerged.

Among 50 respondents, 33 or $66 \%$ were female while 17 or $34 \%$ were male. This inequality is explained by the fact that more female respondents agreed to participate in the experiment.

The distribution of respondents by their institute or high school is the following: 26 or 52\% are from High School of Economics and Management, 24 or $48 \%$ are from High School of Electrical Engineering and Computer Science.

Generally, 25 students which are $50 \%$ are between $18-20$ years of age, followed by the rest or the other $50 \%$ who are between $20-22$ years of age. This can be explained by the fact that mostly second year students were interviewed, some of them entered the university after college, which brings the age difference.

35 educators (lecturers of English) were interviewed to gain data if the educators of SUSU are ready to implement smart technologies or not, what problems they have in using smart technologies in English in the educational process of the university.

\section{$4 \quad$ Results}

The study was designed to gain an insight into bachelors' understanding of smart technologies for learning a foreign language. The results are presented in the form of an answer analysis. The data were interpreted in percentage terms and from the point of view of the most frequently used answers.

\subsection{What types of smart technologies for learning a foreign language do you know?}

We asked students about the types of smart technologies they know which they can use for learning a foreign language. The majority of respondents gave several answers (named more than two types). Our analysis in Fig. 1 shows that social networks (VKontakte), online sites and computer programmes are most frequently mentioned types in students' worksheets.

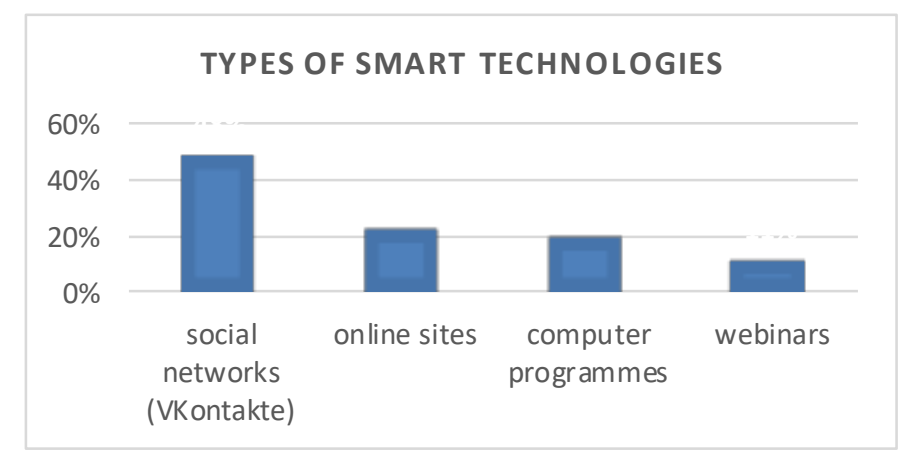

Fig. 1. Types of smart technologies students wrote in their answer sheets by frequency 


\subsection{What types of smart technologies do you use more often at the university?}

Students were also asked what types of smart technologies they use more often at the university. The results are shown below in Table 1. The first two positions by frequency in Table 1 completely coincide with data in Fig. 1. But still we should point out that students are not acquainted with many types of smart technologies, it means that educators do not use them at their lessons. $30 \%$ of students do not use any smart technology at the university.

Table 1. Frequency of smart technologies that students use at the university

\begin{tabular}{|l|c|}
\hline \multicolumn{1}{|c|}{ Type of a smart technology } & Frequency \\
\hline Social networks (VKontakte) & $48 \%$ \\
\hline Online sites & $22 \%$ \\
\hline No use & $30 \%$ \\
\hline
\end{tabular}

\subsection{What is a smart technology used for?}

We analysed all the answers in terms of core notions.

- For comfortable and easy learning of a language $-29 \%$

- For motivating students $-24 \%$

- For solving communicational tasks on one's own - $18 \%$

- For uncovering students' creativity - $16 \%$

- For turning students from passive ones to active participants of the educational process at the university $-13 \%$

\subsection{How often do you use smart technologies for learning a foreign language?}

Students were asked to estimate how often they use smart technologies for learning a foreign language.

$61 \%$ of respondents use different online sites quite often on their own not at the lessons, and 39\% less often. Forty-seven respondents mentioned that smart technologies serve as a means of motivating them to learn a foreign language concerning their communication with foreigners. Among those who use smart technologies very rarely several admitted that they use social networks for educational purposes.

\subsection{Do you think that bachelors should learn basics of smart technologies not only in their native language but in English as well?}

In response to this question, all the respondents answered yes. The follow-up questions were asked in the interview after the questionnaire had been completed. The interview proved the answers gained in the questionnaire.

Educators (lecturers of English) from South Ural State University answered two questions in the interview. 


\subsection{What types of smart technologies would you like to learn how to use in English?}

Educators were asked to put forward suggestions what types of smart technologies they would like to learn how to use in English. The suggestions by respondents are shown in Fig. 2. Almost a half of respondents needed to study all the types. There appear to be differences in the responses to questions about smart technologies in native and foreign languages. The answer "webinars" was not given. "Social networks", "language learning platforms (Cambridge LMS)" and "Moodle" are regarded by educators as most vital in mastering smart technologies.

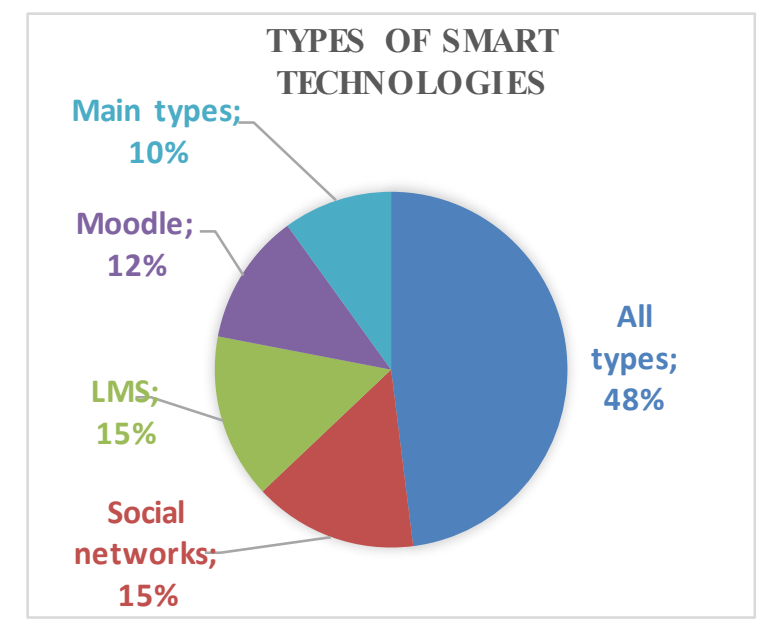

Fig. 2. Needs analysis of educators

\subsection{What challenges do you face in using smart technologies in English?}

We analyzed all the answers in terms of core notions.

- Mastering smart technologies are time-consuming - 35\%

- Educators are afraid of not being able to cope with technical difficulties - $25 \%$

- Educators do not know how to organize their lesson using a smart technology $25 \%$

- Educators consider challenges being a part of the process and not so important, they are ready to cope with all the difficulties and implement smart technologies at their lessons $-15 \%$

\section{Discussion}

The gained results clearly indicate that smart technologies should be widely employed both in learning and teaching foreign languages. Integration of a variety of 
smart technologies obviously helps to alter the way of the language training process and encourage the optimization and modernization of the educational process in general. Having taken into account the results of the needs analysis, the questionnaire and the interview there have been actively applied and integrated some smart technologies facilitating bachelors' language training. Namely there has been specially designed a new online language development course, "English for General Purposes" which was implemented through the Moodle (the university corporate learning management system); we also integrated some language learning platforms (Edmodo, TEDed) and popular social networks (VKontakte, Facebook).

\subsection{The online language development course "English for General Purposes"}

When the educators were asked to suggest the smart technologies that they would like to learn how to use in English, they mentioned the university corporate learning management system Moodle. So in accordance with competence based and cultural approaches there has been designed a new online foreign language development course "English for General Purposes".

This course is targeted at university students of nonlinguistic majors. The main goal of this course is to increase the effectiveness of foreign language learning by providing students with lots of additional materials for studying and working out basic language skills. The online course contains 7 interconnected modules such as Pronunciation, Vocabulary, Grammar, Reading, Listening, Writing and Practical English. All these modules are aimed at integrated development of language skills; development of intellectual potential and encouraging independent activity; individual and needsoriented approach. The course has a simple, intuitive structure and interface that makes it user-friendly even for those who are not tech-savvy at all.

The structure of each unit is unified. Each unit starts with the Pronunciation module which consists of interactive exercises for the differentiation and identification of phonetic units of different kinds, games and quizzes. Special attention is paid to sound-spelling relationships, the stress in multi-syllable words and the situations when the pronunciation of a word may be problematic. As a part of students' pronunciation development throughout the module there is a regular focus on weak forms and silent letters. All phonetic exercises are accompanied by colorful and informative sound pictures which help students identify and produce sounds. As this online course consists of 7 interconnected modules, we decided to emphasize the importance of pronunciation awareness in such grammar and vocabulary topics as the third person singular, plural -s, -ed endings, irregular verbs, prepositions, linking, etc.

The Pronunciation module is followed by the Vocabulary module which starts with an information block (Language Summary). The Language Summary presents the core vocabulary of the corresponding unit and helps to increase the knowledge of high-frequency words and phrases. The examples are given in Table 2. 
Table 2. The name of units and the corresponding vocabulary topics

\begin{tabular}{|l|l|}
\hline \multicolumn{1}{|c|}{ Unit } & \multicolumn{1}{c|}{ Vocabulary } \\
\hline Right place, wrong time & Holidays \\
\hline From rags to riches & Clothes \\
\hline Never smile at a crocodile & Animals \\
\hline How old is your body? & Health and lifestyle \\
\hline
\end{tabular}

A set of interactive lexical exercises (exercises for differentiation and identification of lexical units, exercises for the development of word-building and contextual guesses, exercises for equivalent replacements, etc.) allows to revise and reactivate the lexical minimum of the unit, encourage students to use new vocabulary, use proper vocabulary in the context of specific communicative situations.

The vocabulary module is also interconnected with the Grammar one. All grammar topics are accompanied by related vocabulary to make students able to express themselves on proper lexical and grammar levels and recycle the vocabulary of the unit when doing grammar exercises. The examples are given in Table 3.

Table 3. The grammar topicsand the corresponding vocabulary ones

\begin{tabular}{|l|l|}
\hline \multicolumn{1}{|c|}{ The grammar of the Unit } & \multicolumn{1}{c|}{ Vocabulary } \\
\hline Superlatives & Opposite adjectives \\
\hline Gerund & Verbs followed by -ing \\
\hline Word order of phrasal verbs & Phrasal verbs \\
\hline Past Continuous & Prepositions of time and place \\
\hline
\end{tabular}

In the Grammar module students revise the theoretical material presented in the form of tables and charts. All grammar structures are given in the form of clear and memorable student-friendly reference material. Students are supposed to answer questions on theory and do a set of interactive grammar exercises, thus they are provided with thought-provoking and motivating practice. The module recycles such grammar points as Present, Past and Future Tenses, The Passive, Infinitives and Gerunds, Quantifiers, Reported Speech, etc.

As reading is considered to be important in helping to build vocabulary and consolidate grammar the Reading module satisfies these needs. The texts are selected in accordance with the system of international examinations, so this is the first step towards the international language examinations preparation [18]. Extra Reading section contains engaging and motivating texts, followed by challenging tasks which are aimed to help students to read better, e.g. guess the contextual meaning of words and phrases.

Understanding spoken English is one of the hardest things to master, so students need achievable but at the same time challenging audio materials to develop their confidence and listening skills. The Listening module includes a variety of listening tasks which practise listening for gist and for specific details and also help to prepare for international examinations. All recordings have been chosen for their intrinsic interest and recycle the grammar and vocabulary of the corresponding units. The examples are given in Table 4. 
Table 4. The grammar topics and the corresponding vocabulary ones

\begin{tabular}{|l|l|l|}
\hline The grammar of the Unit & \multicolumn{1}{|c|}{ The vocabulary of the Unit } & \multicolumn{1}{c|}{ Listening } \\
\hline Present Simple & Family, personality adjectives & Who is important to you? \\
\hline Comparatives & Time expressions: spend time, waste time, etc. & Gadget show in London \\
\hline so/neither + auxiliaries & Similiarities & As chalk and cheese \\
\hline
\end{tabular}

It is almost impossible to imagine the modern society without the communication via the Internet, social networks and a variety of mobile applications [19, 20]. So people, especially young people, are writing and communicating in English more than ever. The Writing module provides the students with clear, detailed instructions before they do a guided writing task themselves. These writing tasks review vocabulary and grammar of the unit and are focused on punctuation, spelling, connectors and many other writing skills. The students are supposed to describe themselves, write an informal letter and a formal e-mail, describe a building, give their opinion, etc.

The Practical English module presents tasks which help students understand highfrequency phrases in common situations, e.g. checking in at the airport; provide them with some strategies, e.g. how to cope with typical travel and restaurant problems and what to say in typical situations, e.g. at a department store or at a pharmacy; introduce new challenges, e.g. making a phone call.

This new online foreign language development course "English for General Purposes" allows educators to have more time for the speech practice at their lessons as students are supposed to get acquainted with all the necessary information at any time convenient to them and have already prepared questions [21].

\subsection{Social networks (VKontakte, Facebook)}

Our analysis shows that social networking is the most frequently used smart technology type. Even those who hardly ever use any smart technologies admit that they use social networks for educational purposes. The most frequently named social network is VKontakte. We also chose Facebook as it is popular worldwide and will help students integrate into the world community and has interface in English. So these two social networks were introduced into bachelors' foreign language teaching process.

Social networks provide a huge range of instant communication tools and leisure activities, thus they seem to be appealing to young people and have the potential to be used for educational purposes as well. Students and educators create blogs, miniblogs, interest groups, also upload their project works, videos, pictures, audio files; they take part in online debates. So VKontakte was implemented for the project "Our Music Group". The students were supposed to invent a new music band, give it a name, make an album/CD cover. They were also to write a biography for each band member, including the background of the band. and record an interview with the band members. The other students took an active part in commenting the band online, interacting with them and having further offline discussions. There were even created some fan clubs [22]. 
All these social networking tools provide interactivity and create engaging foreign language learning environment. Educators can include links to other sites or resources, this way they provide additional information and enrich the topics and themes that have been discussed in the classroom. All students are encouraged to post their comments, take active part in discussions and share the related information. Consequently students are motivated to exchange their ideas, opinions and contribute to the learning environment. Some students seem to be too shy to air their views in the classroom or they need more time to think and make up their ideas and so they are just not able to provide an instant response. Posting comments eliminates these difficulties and as a result students have a nice opportunity to develop their writing skills, interactive cooperation and independent learning.

Implementation of social networking in the process of foreign language learning stimulates higher academic achievements, active collaboration and contribution by sharing ideas and useful links to other sites and articles or videos of interest. Thus students become not only passive consumers of information, but active participants of the educational process.

\subsection{Language learning platforms (Edmodo, TEDed)}

The results of the educators' interview show that language learning platforms are regarded vital in mastering smart technologies. The majority of students also mentioned online sites for the purpose of learning foreign languages, but they found it difficult to name any definite sites. To satisfy the needs of students and educators there were chosen and widely implemented two language learning platforms Edmodo and TEDed. They provide free and secure educational learning environment as well as create the opportunity to model effective virtual collaboration and improve learning effectiveness.

The Edmodo network is one of the most popular and widespread language learning platforms for educators, students and their parents. Its interface is in English and it motivates students to broaden their foreign language skills. It provides huge opportunities for interaction and collaboration as educators can create and manage an online student community thus improving and encouraging communication and interaction. Educators can download questionnaires and get the immediate feedback from their students and adjust classroom activities accordingly. And it is a very convenient platform for uploading language quizzes, tests, video and audio sources, links to useful resources. Students usually process this information in their free time and so educators encourage after-class academic pursuits and improve individual learning skills.

TED Conferences LLC (Technology, Entertainment, Design) is a media organisation that is gaining more and more popularity. One of its educational projects TEDed has been implemented into the process of bachelors' language training. So for the project "Wonders of the World" the students were encouraged to join this community, watch the related videos and do a number of tasks: make up the vocabulary list to a related topic, make a summary, pick the most intriguing ideas, comment on the most striking ideas, etc. The results of their work were discussed online and in the classroom when students made their presentations about human wonders (places, shopping 
malls, monuments, buildings, bridges, restaurants, stadiums, cities, countries, etc); natural wonders (deserts, islands, mountains, oceans, seas, lakes, rivers, glaciers, etc ); 'world records' (the best, the worst, the longest, the shortest, etc).

So students do not just passively watch the videos, but they are supposed to take active part in discussions and contributing their comments, reviews, etc.

This engaging learning environment motivates students to develop their language skills, maintains their enthusiasm and as a result it leads to very positive learning outcome.

\section{Conclusion}

The designed study to gain an insight into bachelors' understanding of smart technologies for learning a foreign language has revealed that the majority of students have no clear understanding of smart technologies types. It leads to the conclusion that educators hardly ever implement any smart technologies at their lessons. The results of the study also show that educators have low level of smart technologies awareness. Utilizing these technologies is usually blocked by technical difficulties and lack of time for mastering them.

However, students as well as educators are very positive about mastering and implementation of smart technologies into the process of language training. We believe that the traditional approach to foreign languages teaching must be supported by modern and up-to-date smart technologies as they are mutually supportive and lead to higher academic achievements. Educational institutions should rethink and modernize their policies on the wide integration of smart technologies as it is not enough any more just to transfer knowledge and make students literate. Every student has his or her own learning style, needs and requirements. A variety of smart technologies provides resources and tools to satisfy this diversity, make the learning environment more engaging, encourage the optimization and modernization of the educational process.

Systematic employment of smart technologies and their appropriate selection by educators can eliminate the blocking factors and make these technologies effective. Proper integration of smart technologies into classroom activities and students' individual work will definitely promote learning opportunities and the development of language skills.

\section{$7 \quad$ Acknowledgement}

The work was supported by Act 211 of the Government of the Russian Federation, contract №02.A03.21.0011. 


\section{References}

[1] Yu, Yanan; Qi, Aili. (2018). Teaching System of Smart Learning Environment for Aerobics Course. International Journal of Emerging Technologies in Learning (iJET), [S.l.], v. 13, n. 05, pp. 165-176, doi: http://dx.doi.org/10.3991/ijet.v13i05.8440

[2] Sung, Y.-T., Chang, K.-E., Liu, T.-C. (2016). The effects of integrating mobile devices with teaching and learning on students' learning performance: a meta-analysis and research synthesis, Computers and Education, vol. 94, pp.252-275. https://doi.org/10.1016/j.com pedu.2015.11.008

[3] Sheehan, M., Nillas, L.A. (2010). Technology integration in secondary mathematic classrooms: effect on students' understanding, Journal of Technology Integration in the Classroom, vol. 2, no. 3, pp. 67-83

[4] Falloon, G., Janson, A., Janson R. (2010). Learning objects and the development of students' key competencies: a New Zealand school experience, Australasian Journal of Educational Technology, vol. 26, no. 5, pp. 626-642. https://doi.org/10.14742/ajet.1055

[5] Cetto, M. (2010). Technology and second language teaching, Brujula, vol. 8

[6] Menkhoff, T., Bengtsson, M. (2012). Engaging students in higher education through mobile learning: lessons learnt in a Chinese entrepreneurship course, Educational Research for Policy and Practice, vol. 11, no. 3, pp. 225-242. https://doi.org/10.1007/s10671-0119123-8

[7] Shim, J.P., Dekleva, S., Chengqi, G., Mettleman, D. (2011). Twitter, Google, iPhone/iPad, and Facebook (TGIF) and smart technology environments: how well do educators communicate with students via TGIF?, Communications of the Association for Information Systems, vol. 29, article 35, pp. 657-672. https://doi.org/10.17705/1cais.02935

[8] Johannesen, T., Eide, E.M. The role of the teacher in the age of technology: will the role change with use of information and communication technology in education? [Online]. Available: http://www.eurodl.org/materials/contrib/2000/eide3/eide3.html

[9] Durocher, K. The importance of balancing classroom technology use. [Online]. Available: http://gettingsmart.com/2016/12/technology-productively-in-the-classroom/

[10] Kuang-wu, L. English teachers' barriers to the use of the computer-assisted language learning. [Online]. Available: http://iteslj.org/Articles/Lee-CALLbarriers.html

[11] Pugachev, A. (2018). Smart-technologies in teaching financial disciplines to students of higher educational institutions, Current Problems of Developing Higher Education, pp.362-364

[12] Kalugina, O., Tarasevich, N. (2018). Smart technology integration into EFL teaching at the non-linguistic higher school, XLinguae, vol. 11, no. 1XL, pp. 8-18. https://doi.org/10.18 355/xl.2018.11.01x1.02

[13] Andrade, M. Role of technology in supporting English language learners in Today's Classrooms. [Online]. Available: https://tspace.library.utoronto.ca/bitstream/1807/66995/1/ Andrade MariadeLourdes 201406 MT MTRP.pdf

[14] Konnova, Z., Gladkova, O. (2017). Didactic peculiarities of teaching a foreign language for academic and scientific purposes in smart-education, Bulletin of Tula State University. Series: Pedagogy, vol.1, pp. 88-96

[15] Esina, L. (2017). The use of smart technologies in the system of part-time education, New Science: Theoretical and Practical Views, vol. 2, no. 4, pp.62-64

[16] Stepapenko, E., Zelikovskaya, E. (2017). Smart-technologies in teaching a foreign language for professional purposes, Bulletin of National University of Bioresources and Natural Resources Management of the Ukraine. Series: Phylology, vol. 263, pp. 186-193 
[17] Zhdanov, E., Barinova, N., Magsumov, I., Yafizova, R. (2015). The construction of individual educational trajectories of students' training on the basis of smart technologies in the conditions of modernization of education, Kazan Pedagogical Journal, vol.3, pp. 34-39

[18] Guo, Lan et al. (2017). Design and Implementation of English Reading Examination System Based on WEB Platform. International Journal of Emerging Technologies in Learning (iJET), [S.1.], v. 12, n. 12, pp. 45-56. http://dx.doi.org/10.3991/ijet.v12i12.7959

[19] Shi, Shaohua. (2016). Computer English Teaching Model Based on Multimedia Platform. International Journal of Emerging Technologies in Learning (iJET), [S.1.], v. 11, n. 08, p. pp. 59-64. http://dx.doi.org/10.3991/ijet.v11i08.6050

[20] Kuzmina, N., Kochkina, D. (2017). Implementation of the model of forming the future managers' readiness for business correspondence in the educational process of the university, ICERI2017 Proceedings, 10th annual International Conference of Education, Research and Innovation, 16th - 18th of November, pp. 2658-2662. https://doi.org/10.21125/ iceri.2017.0758

[21] Kochkina, D., Kuzmina, N. (2017). Innovative technologies employment as a support in the process of foreign languages teaching, ICERI2017 Proceedings, 10th annual International Conference of Education, Research and Innovation, 16th - 18th of November, pp. 2653-2657. https://doi.org/10.21125/iceri.2017.0757

[22] Mason, R., Rennie, F. (2007). Using Web 2.0 for learning in the community. The Internet and Higher Education, 10, 196-203. https://doi.org/10.1016/j.iheduc.2007.06.003

\section{Authors}

Renata Elsakova is an educator of the Foreign Languages Department at South Ural State University, Chelyabinsk, Russian Federation.

Nadezhda Kuzmina is an associate professor of the Foreign Languages Department at South Ural State University, Chelyabinsk, Russian Federation.

Darya Kochkina is a senior educator of the Foreign Languages Department at South Ural State University, Chelyabinsk, Russian Federation.

Article submitted 2019-03-27. Resubmitted 2019-05-20. Final acceptance 2019-05-28. Final version published as submitted by the authors. 